\title{
Reduction, Fusion and Raising in English and Spanish
}

\author{
Francisco Garrudo Carabias \\ Universidad de Sevilla
}

\begin{abstract}
The reduction of clauses, together with the fusion of structures, is a source of syntactic problems especially isomorphism and structural ambiguity both in English and Spanish. Raising and Equi-NP Deletion are the processes responsible for them. Raising operates in English more often than in Spanish and under different conditions. The syntactic complication of these phenomena for a non-native speaker and the advantage of a possible reference to similar cases, although more restricted, in Spanish, makes a comparative study of these processes very useful. Ignoring the formal technicalities of Transformational Grammar, this paper analyses, compares and contrasts the conditions of operation of raising in English and Spanish.
\end{abstract}

The aim of this paper is to comment on the problems raised by a specific set of structures which are very common in English but not so in Spanish. ${ }^{1}$ Such structures appear superficially as reduced clauses in a sequence of $\mathrm{NP}+\mathrm{VP}+$ infinitive $^{2}$ after the NP-Movement known as raising (for instance, «She happened to see you,» «She is likely to come» or «She is a pleasure to talk to»).

\section{Clause Reduction}

A reduced-as opposed to full-clause is «any clause which is incomplete in either or both of these senses: in that at least one potential element of a main clause, or at least one of the potential categories of its predicator, is excluded» (Matthews 173). Thus, any clausal infinitive that is embedded in a matrix sentence constitutes a reduced clause.

Consider the following sentences (the pre-surface structure is given between square brackets):

1) Mary wants to come [Mary wants (Mary comes)]

2) María quiere venir [María quiere (María viene)]

3) Mary wants John to come [Mary wants (John comes)]

4) María quiere que Juan venga [María quiere (Juan viene)] 
Both 1 and 2 contain reduced clauses since, first, the non finite forms «to come» and «venir» lack a subject which must be searched for in the linguistic context and, second, they also lack the inflections and other features (tense, aspect, etc.) characteristic of any VP in a full clause. On the other hand, whereas 3 contains a reduced clause, its counterpart in Spanish does not, since «venga» in 4 is a tensed form with an overt subject.

Clause reduction is much more frequent in English than in Spanish, where it seems to be constrained by a kind of rule that blocks it unless there is coreference of subjects (cfr. example 4 above) with some exceptions (see sentences 8 and 9 below, and endnote 3). Contrast the following sentences:

5a) He brought his glasses to see me

5b) He brought his brother to see me

6a) We make shoes to last

6b) We make shoes to survive

7) We chose a lawyer to protect our interests

In every case we find purpose adverbial clauses that have been reduced. The understood subject of the infinitive changes according to semantic or pragmatic factors which both speakers and hearers must be aware of when encoding or decoding.

In $5 b$ the implied subject of «see» is «his brother» while the analogous NP in 5a, «his glasses,» can neverr be taken for the subject of the homologous structure, for obvious semantic reasons. English relies on this fact and does not take into account the syntactic ambiguity caused by clause reduction because the semantics of the units in the sentence makes the meaning clear. In contrast, and despite the semantic disambiguation, Spanish does not allow a reduced clause in 5b: «Trajo a su hermano para que me viera/*verme» vs. «Trajo sus gafas para verme.»

We find a similar case in 6 . This time the selectional restrictions of «survive» in $6 b$ make us choose «we» as its understood subject, whereas in 6a the implied subject of «last» must be «shoes,» for the same reason. Note that the counterparts of these sentences in Spanish are structurally different from each other since they can never be both reduced: «Hacemos zapatos para que duren» vs. «Hacemos zapatos para sobrevivir.» Spanish tends to block reduction when the understood subject of the embedded clause is not the same subject of the matrix verb.

In 7 we face a real structural or constructional ambiguity caused by clause reduction. Now it is the linguistic or situational context that must clarify the meaning. The understood subject of «protect» may be either «we» (i.e. «We tried to protect our interests by choosing a lawyer») or «a lawyer» (i.e. «We chose a lawyer so that he protected our interests»). As usual, only under the first interpretation can the adverbial reduced clause be fronted: «To protect our interests we chose a lawyer.»

This time Spanish seems to permit a reduced clause in both cases: «Escogimos a un abogado para defender nuestros intereses» is as ambiguous as 7 in English although "para que defendiera nuestros intereses» is preferred when there is a change of subjects.

As a matter of fact Spanish also depends on semantics and pragmatics sometimes, and seems to allow clause reduction when the meaning is exceptionally unambiguous. Contrast: 
8) Le pedí dinero para coger un taxi

9) Le presté dinero para coger un taxi

Now we find clause reduction and constructional ambiguity in both cases despite the fact that in 9 the understood subject of «coger» is not the subject of the matrix verb. The clear disambiguation provided by the semantics of PEDIR and PRESTAR allows these structures to become superficially alike. ${ }^{3}$

\section{Fused Construction}

Clause reduction very often involves an additional syntactic phenomenon: the fusion of constructions. A fused construction is «any in which a single element is a complement of both a controlling and a dependent predicator» (Matthews 185). Consider a sentence such as:

10) My old friend sings many beautiful songs

A dependency tree diagram would account for its structure in the following way:



If we substitute arrows for the branches we get the following picture, equivalent to the tree above (notice that the arrows point towards the dependent terms):

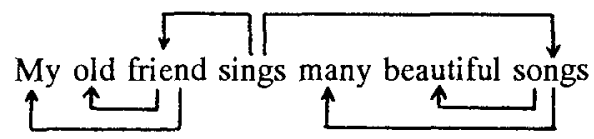

Such construction is not fused since no term appears as a double complement and therefore we do not find two arrows pointing towards any element. Contrast it with these sentences:
11) I find her pretty
L J
12) Peter tried to see Mary
13) I hate her to say that 
«Her» in 11 is at once the object of «find» and the subject of the predicative adjective «pretty.» In 12, «Peter» is a subject of both «tried» and «see.» Finally, «her» in 13 is at once the object of «hate» and the subject of «say.» This schizophrenic behaviour - a single element with a double complementing function-is typical of fused constructions. ${ }^{4}$

Sentence 11 is just a fused construction, while 12 and 13 are fused constructions and also contain reduced clauses: the matrix verbs TRY and HATE are therefore catenatives since they mix a dependent verbal construction with a transitive or intransitive structure. ${ }^{5}$

If this analysis is extended to adjectival complementation we find analogous patterns with some adjectives followed by infinitives:

14) $\sqrt{r \text { is anxious to talk to }}$

14) Peter is anxious to talk to Mary

15) Peter is too important to talk to

The difference between 14 and 15 lies in the kind of dependency relation maintained between the initial NP, «Peter,» and the infinitives: whereas in 14 «Peter» is a double subject of «(is) anxious» and «talk to,» the structure being thus equivalent to that of 12 above, «Peter» in 15 is the subject of «(is too) important» but the object of «talk to.» ${ }^{6}$

Contrast these structures with 16 where there is clause reduction but no fusion of constructions has been produced-we do not find two arrows pointing at any element:

16) It is important to do it at once

structurally equivalent to «That is important» and where «it» = «to do it at once.»

\section{Raising}

In the progression from deep to surface structure a given element belonging to a specific level may be moved up to a higher level thus becoming a complement of a matrix verb which does not have such an element as one of its arguments. ${ }^{7}$ In functional terms, a given element which is originally a subject or an object in a dependent or embedded clause becomes a subject or an object of the matrix verb. The term raising expresses the fact that the element affected by this process is raised to an upper level in the tree diagram. ${ }^{8}$ As a result, the sentence that is deprived of one of its elements gets reduced and the verb changes to infinitive.

Raising must be contrasted with Equi-NP Deletion, a similar process that operates independently. Equi-NP Deletion also causes clause reduction through the deletion of one element (a noun phrase) that appears twice (hence the term Equi-NP Deletion) in 
two different clauses. As a result, again, since the verb loses its subject, it changes to infinitive. Contrast the following examples:

17) She expects that you will come - Ella espera que vengas (no raising, no Equi-NP Del.)

18) She wants to come - Ella quiere venir (Equi-NP Del. from «She wants [she comes]» and «Ella quiere [ella viene],» respectively)

19) She wants him to work harder (raising from «She wants [he works harder]»)

20) She asked him to work harder (Equi-NP Del. from «She asked him [he works harder]»

21) She promised him to work harder (Equi-NP Del. from «She promised him [she would work harder]»

Returning to our original question and if we consider the evolution of the element involved, a raising may be subject-to-object, object-to-object, object-to-subject or subject-to-subject, the first term indicating the original or deeper function and the second one, obviously, the terminal function.

\section{A. Subject-to-Object Raising}

22) I hate her to say that [I hate (she says that)]

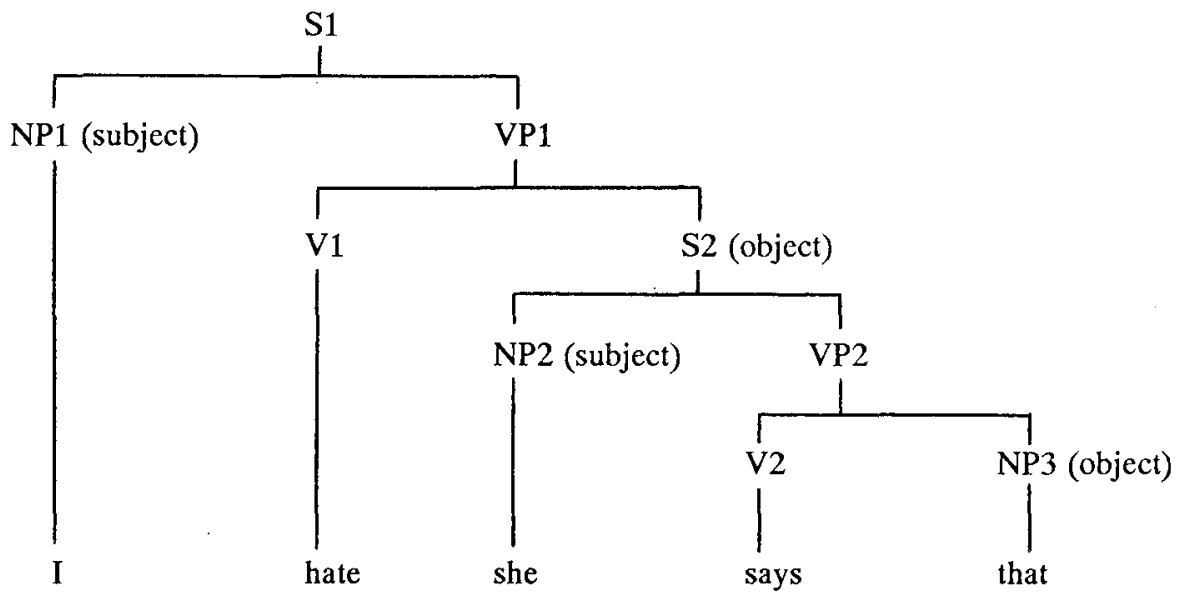

«Her» is an argument of «says,» not of «hate» since «I hate her to say that» does not mean «I hate her.» Nevertheless in the surface structure, by means of the process of raising, «she» has been moved up and made the surface object of «hate.»

In the Spanish version of this sentence raising does not apply and the original structure comes out directly (once the complementizer «que» is included): «Detesto que ella diga eso.» 
This kind of raising may apply in Spanish with physical perception verbs (VER, OÍR, etc.) as well as with HACER, DEJAR, PERMITIR: «Te vi correr» $(\leftarrow$ Vi que tú corrías), «Te oí cantar» ( $\leftarrow$ Oí que tú cantabas), «Me hicieron venir» ( $\leftarrow$ Hicieron que yo viniera), «No te quiero oir decir eso» ( $\leftarrow$ No quiero oir que tú dices eso. Notice the obligatory double raising, since QUERER behaves as a kind of semiauxiliary in a complex VP), etc.

This concept of raising can be extended to certain verbs (QUERER, NECESITAR, VER, CREER and, under very special conditions, SABER) when the dependent verb is SER or ESTAR and the structure becomes complex transitive after the infinitive is dropped: «Te quiero más alegre» ( $\leftarrow$ Quiero que estés más alegre), «Quiero el café más caliente,» «Te quiero aquí a las 7 ,» «Os necesito a las 4 ,» «La vi muy tranquila,» «Ella te cree muy inteligente,» «Te creía en Londres,» «Estaba muy nervioso sabiéndote entre el público,» etc. ${ }^{9}$

\section{B. Object-to-Object Raising}

23) María te quiere ayudar $\leftarrow$ María quiere ayudarte [María quiere (María te ayuda)]



«Te» is an argument of «ayuda,» not of «quiere» (cfr. the difference between «María te quiere» and «María te quiere ayudar»). After the Equi-NP Deletion, which removes the NP2 since it is coreferent and coindexed with NP1, we get «María quiere ayudarte,» a reduced clause which is the first possibility if raising does not apply. If raising does apply ${ }^{10}$ «te» is transferred from the object function in the dependent clause to the object function in the matrix, thus resulting in the other possibility expressed in 23 .

The only possibility I can think of in English is far from clear since it involves a semiauxiliary verb, HAVE TO, which after the raising changes to fully lexical and loses a great deal of its modality: «I have to write many letters» $\rightarrow$ «I have many letters to write.» 


\section{Object-to-Subject Raising}

24) Peter is easy to persuade

$\leftarrow$ It is easy to persuade Peter

[(everybody persuades Peter) is easy]

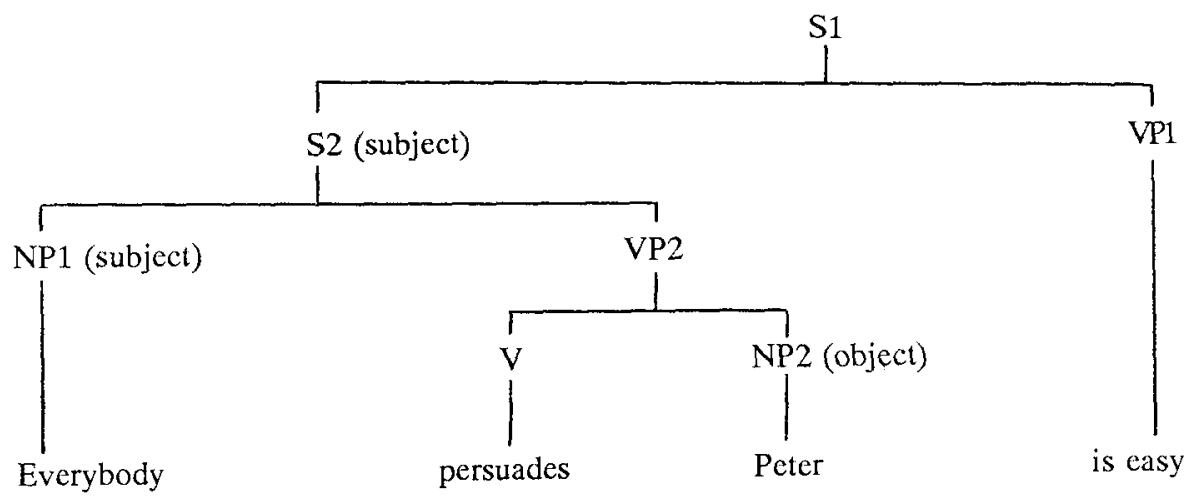

The universal subject of «persuade» is dropped and the verb comes out as an infinitival subject if raising does not apply: «To persuade Peter is easy» $\rightarrow$ «It is easy to persuade Peter,» after IT Anticipation. If raising does apply, «Peter» is raised to the subject position in front of «is easy.»

«Peter» is not an argument of «(is) easy.» The «easiness» is predicated not of Peter but of the action as a whole. In a dependency diagram this fact would be expressed thus:

25)

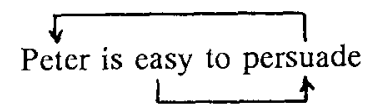

Notice that no arrow goes from «easy» towards «Peter.» Contrast this structure with the one exemplified in 15: «Peter» is an object of the infinitive in both 15 and 25 , but in 15 «Peter» is also the subject of «important.» 15 is, therefore, a fused construction, 25 is not.

This type of raising also happens in Spanish, with one additional change: when raising operates and the adjective is immediately followed by the infinitive they get linked by the usual modifying preposition DE:

26) Persuadir a Pedro es fácil/difícil/imposible/etc.

Es fácil/difícil/imposible/etc. persuadir a Pedro

$\rightarrow$ Pedro es fácil/difícil/imposible/etc. DE persuadir

Nevertheless, this process is less feasible in Spanish than in English, where any complement can be raised (or topicalized), ${ }^{11}$ whereas in Spanish it is limited to objects. Contrast the following instance: 
27) It is easy to play sonatas on this violin

$\rightarrow$ This violin is easy to play sonatas on

$\rightarrow$ Sonatas are easy to play on this violin ${ }^{12}$

In Spanish they have to be raised from different original structures:

28) Es fácil tocar las sonatas con este violín

$\rightarrow$ Las sonatas son fáciles de tocar con este violín

$\rightarrow$ *Este violín es fácil de tocar las sonatas

29) Es fácil tocar este violín

$\rightarrow$ Este violín es fácil de tocar

\section{Subject-to-Subject Raising}

30) Mary appears to love John

$\leftarrow$ It appears that Mary loves John

[(Mary loves John) appears]

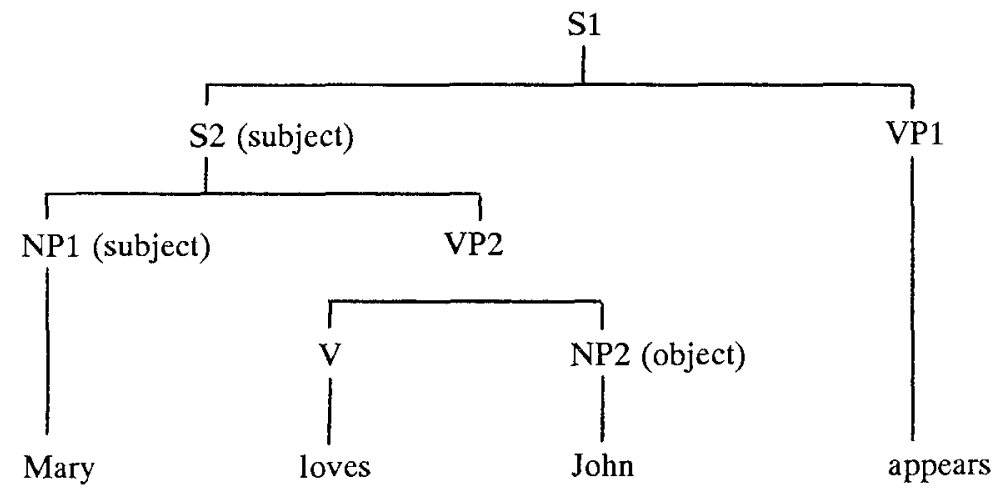

«Mary» is an argument not of «appear» but of «love.» «Appear» contains the whole clause «Mary loves John» as its only argument and as such it may come out to the surface if raising does not apply: «That Mary loves John appears» $\rightarrow$ «It appears that Mary loves John.»

But if raising does apply, then «Mary» is taken up to the matrix and as result «loves» changes to the infinitive because of the reduction, eventually resulting in «Mary appears to love John.»

In a dependency diagram this fact is expressed as follows (notice the absence of arrow between «Mary» and «appears»):

31) Mary appears to love John

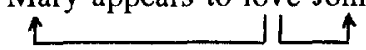


«Appear» predicates of the process. Contrast it with 12 , where «tried» predicates of «Peter.» Raising can be interpreted as a kind of syntactic metonymy since a characteristic of the whole, of the total process, is transferred to one of the arguments.

Consider now the two possible interpretations of the following sentence: ${ }^{13}$

32) He promises to be a pianist

a) He promises to be a pianist

In 32a «He» is an argument of «promise»: we are reporting the performance of a promise by somebody ( $\mathrm{PROMISE}_{1}$ is a performative verb). This structure is analogous to 12 above. If fusion does not operate the meaning does not change: «He promises that he will be a pianist.»

This is something that cannot be done with $32 \mathrm{~b}$ where we are reporting a fact that «promises» to be so in the future, i.e. the fact that somebody is going to be a pianist seems to be likely to happen in the future. That is the meaning of PROMISE $E_{2}$ : present likelihood of a process in the future, or present apparentness of a future process.

«He» in $32 \mathrm{~b}$ has been raised from the dependent clause to the matrix: $[(\mathrm{He}$ is a pianist) promises] $\rightarrow$ «He promises to be a pianist.» This sentence is analogous to 31 . Notice that the same ambiguity happens in Spanish:

\section{3) El promete ser pianista}

As a matter of fact there are at least two verbs PROMISE in English, as well as there are two verbs PROMETER in Spanish, and this lexical ambiguity combined with the processes of Clause Reduction and raising cause the constructional ambiguity in both languages.

Whether in the present or in the past, APPEAR with a raised subject may express both simultaneity of the process and its apparentness («He appears to be a pianist» «It appears that he is a pianist,» «He appeared to be a pianist» $\leftarrow$ «I . appeared that he was a pianist») and anteriority of the process with respect to its apparentness $(\ll \mathrm{He}$ appears to have been a pianist» $\leftarrow$ «It appears that he has been a pianist,» «He appeared to have been a pianist» $\leftarrow$ «t appeared that he had been a pianist»).

But no derivation through raising, without lexical change of APPEAR, is possible for posteriority of the process with respect to its apparentness. PROMISE with a raised subject may express that gap in APPEAR: «It appears that he will be a pianist» $\rightarrow$ «He promises to be a pianist.»

The inherent idea of posteriority of the objective argument of PROMISE may be transferred to the English infinitive, which lacks a morpheme for posteriority (cfr. in Latin, «Te venire scio,» «Te venisse scio» and «Te venturum esse scio»), although the plain infinitive can be understood as future when pragmatic factors make this meaning 
clear: contrast «I want (now) him to be a pianist (in the future),» vs. «I know (now) him to be a pianist (now/*in the future).»

Subject-to-subject raising explains the syntactic behaviour of the following groups of words in English:

D1) Some verbs of appearance, happening and result: APPEAR, SEEM, HAPPEN, CHANCE, TURN OUT.

34) Mary appears to be innocent

35) Mary seems to like the book

36) Mary happens to be in London

37) Mary chanced to be in London

38) Mary turned out to love John

These verbs are predication qualifiers, very close to epistemic modals: $:^{14}$ they express a kind of modality (possibility, probability, appearance, etc.) which can be transferred from the sentence to one of the actants. In most cases there is an alternative with a Modality Disjunct: APPARENTLY, SEEMINGLY, BY CHANCE, EVENTUALLY, etc. (cfr. «Apparently, Mary is innocent»), as well as an alternative with the verb predicating of the clause with a non-raised subject in a structure closer to the deep structure (cfr. «It appears that she is innocent»).

Another special feature of these verbs is their acceptance of empty IT and THERE as surface subjects, which argues for their semiauxiliary character:

39) It seems to be raining (vs. It is raining)

40) It chanced to rain ( $\nu s$. It rained)

41) There seem to be many people outside ( $v s$. There are many people outside)

Only Auxiliaries behave this way: cfr. «It must be raining,» «There may be many people outside.»

SEEM and HAPPEN allow the passivization of the whole sentence without change of the propositional meaning, which proves again that they are more like Auxiliaries in terms of passivization. Contrast their behaviour with that of WANT, for instance:

42) Peter seems to love Mary = Mary seems to be loved by Peter $^{15}$

43) Peter happens to love Mary = Mary happens to be loved by Peter

44) Peter wants to help Mary $\neq$ Mary wants to be helped by Peter

«Peter» is an argument of WANT in 44. If we passivize the whole sentence there is a change of actants and as a result the propositional meaning changes completely. This does not happen with Auxiliaries (cfr. «Peter may help Mary» = «Mary may be helped by Peter»). SEEM and HAPPEN are, in this respect, very much like Auxiliaries.

Furthermore, like with the epistemic modals, the sentences that contain SEEM and HAPPEN may have two time references: a reference to a past event (expressed by the lexical verb in infinitive) and reference to present «happening» or "seeming.» In other words, an event may have happened in the past but the speaker expresses its present modal implications (see the discussion on APPEAR and PROMISE after example 33). 
This results in the occurrence of these verbs in the present tense with a past infinitive, i.e. a HAVE form of the following infinitive:

45) Peter seems to have helped Mary (i.e. Now it seems that Peter helped Mary)

46) Peter happens to have helped Mary (i.e. It happens that Peter helped Mary, It is relevant now that Peter helped Mary in the past)

This is the same behaviour of the MUST of epistemic modality, for instance:

47) Peter must have helped Mary

(i.e. Now it appears as probable that Peter helped Mary)

In Spanish there seem to be very few verbs affected by subject-to-subject raising. Two examples would be PARECER and PODER, the latter with the epistemic meaning of «probability.» Most of the features mentioned for HAPPEN and SEEM apply to them:

48) Pedro parece estar enamorado de María

(cfr. Parece que Pedro está enamorado de María, Aparentemente Pedro está enamorado de María, Pedro parece haber estado enamorado de María)

49) Pedro puede estar enamorado de María

(cfr. Puede que Pedro esté enamorado de María, Posiblemente Pedro esté enamorado de María, Pedro puede haber estado enamorado de María) ${ }^{16}$

D2) Three adjectives of prediction or future probability are also affected by this process: LIKELY, CERTAIN and SURE, but not PROBABLE. Some of the features mentioned for SEEM and HAPPEN appear to be valid for them too. Notice that the division present modality/future event is obligatory with these adjectives:

50) Peter is likely/certain/sure to see Mary ${ }^{17}$

(cfr. It is likely/certain that Peter will see Mary, Peter will see Mary, that's sure)

51) *Peter is probable to see Mary

(cfr. It is probable that Peter will see Mary)

I have not found any adjective in Spanish with these syntactic possibilities.

D3) Subject-to-subject raising can be extended to a wide set of verbs of physical perception, rational reception, reporting, saying, believing, etc. to explain their behaviour when they raise a passivized subject. BELIEVE, FIND, SUSPECT, DISCOVER, SAY, EXPECT, ASSURE, KNOW, REPORT, THINK, CONSIDER, HOLD, SUPPOSE, ADMIT, SEE, are some of these verbs, which allow the raising of the dependent subject after passivization. ${ }^{18}$

52) He is believed to be innocent

(Everybody believes that he is innocent $\rightarrow$ It is believed that he is innocent, through ${ }^{*}$ That he is innocent is believed) 
«He» is not an argument of «believe.» It is the whole sentence that is the object of everybody's belief. Compare it with «He appears to be innocent» $\leftarrow$ «It appears that he is innocent.»

53) He was expected to marry Jane

54) He was thought to have killed his wife

55) He is known to be a spy ${ }^{19}$

DECLARAR, CONSIDERAR and ENCONTRAR behave similarly in Spanish but raising is limited to the presence of SER as a dependent verb which is dropped after the raising (see endnotes 9 and 19 , and section $A$, above):

56) Pedro fue considerado/declarado/encontrado culpable

(Se consideró/encontró/declaró que Pedro era culpable

$\leftarrow$ Consideraron/encontraron/declararon que Pedro era culpable)

( $c f r .{ }^{*}$ Pedro fue considerado/declarado/encontrado haber matado a su esposa)

\section{Notes}

1. This is a revised version of Garrudo «Some Aspects of Contrastive Syntax.»

2. NP: noun phrase; VP: verb phrase.

3. All the examples given so far to illustrate clause reduction contain purpose adverbial clauses. With certain verbs involving nominal infinitives in ditransitive complementation (DEJAR, PERMITIR, MANDAR, PROHIBIR, PEDIR, ROGAR, etc.) and those of physical perception (VER, OIR, etc.) Spanish allows clause reduction and change of subjects, once again for obvious semantic reasons (cfr. «No te permito decir eso,» «Ella te oyó decir eso»). For a description of such structures in Spanish see Cano 136-158 and 347-355. Nevertheless, English has greater freedom than Spanish to reduce clauses. Contrast the following sentences in English, all of them different in their deep structure, with their versions in Spanish:

He brought John to see me (Trajo a Juan para que me viera)

He asked John to see me (Pidió a Juan que me viera)

He wanted John to see me (Quería que Juan me viera)

He ordered John to see me (ambiguous: Ordenó a Juan que me viera, vs. Ordenó que Juan me viera)

He promised John to see me (Prometió a Juan que me vería)

4. Cfr. Culicover 255.

5. On this question cfr. Palmer 166-211 and Huddleston An Introduction to the Grammar 211-215.

6. There is very often ambiguity due to clause reduction, as usual between these two interpretations when the verbs in infinitive are used both transitively and intransitively. Contrast:

I am ready to eat (Estoy listo para comer)

The omelette is ready to eat (La tortilla está lista para comerla) 
He is too old to teach (ambiguous: Es muy mayor para dar clase/darle clase)

$\mathrm{He}$ is too old to learn (unambiguous)

$\mathrm{He}$ is the right man to choose (ambiguous: Es el hombre apropiado para elegir/ser elegido)

$\mathrm{He}$ is too good a person to swindle (ambiguous: Es demasiado bueno para timar/timarle)

7. On this subject $c$ fr. Postal, and Radford 184-90, 324-37.

8. Note that now we are using simplified phrase structure markers, not dependency trees.

9. Cfr. Cano 155, 186, 203 y 250 . For an analysis of perception verbs in English $c f r$. Akmajian.

10. This kind of raising seems to be constrained by the existence of pronoun replacement of the object. In every case we find pronouns in the matrix clause: «Lo sé hacer,» "Lo mandé traer,» «Lo vi sacar del baúl,» «Me lo dejaron hacer» ( $\leftarrow$ Me dejaron hacerlo, where «me» has not been raised since it is an argument of «dejar» functioning as an indirect object).

11. Both object-to-subject raising and subject-to-subject raising can be considered processes of topicalization or thematization: by raising one element to the main subject position not only is the syntactic structure of the sentence changed but also its thematic organization. Consider the change of theme in the examples given in 27, 28 and 29. This may happen in English with nouns too: «Peter is a pleasure to teach» ( $\leftarrow$ It is a pleasure to teach Peter), «Peter is fun to be with.» This capacity affects passivization in English, a much more powerful instrument of topicalization than in Spanish.

12. Examples taken from Huddleston An Introduction to English 27.

13. Example taken from Matthews 189.

14. Cfr. Palmer 1135-39, 208-9 and Huddleston An Introduction to the Grammar 211-15.

15 . Obviously the thematic meaning does change.

16. The subjunctive is required when a finite form of the lexical verb is used, due to the idea of possibility. Note that the same may happen in 48 if the idea of possibility is stressed: «Parece que Pedro esté enamorado de María,» «Parece como si Pedro estuviera enamorado de María.»

17. SURE and CERTAIN have homonyms meaning «having no doubt.» These predicate not of the whole sentence but of the actant that appears as subject, they are followed by THAT Clauses and cannot be raised: «Peter is sure/certain that he saw me yesterday.» Contrast it with «It's sure to rain» where there is no actant and SURE predicates of the whole sentence. $C f r$. in Spanish the difference between «ser seguro» and «estar seguro»:

Estoy seguro (de) que lloverá, vs.

Es seguro que lloverá, Seguramente lloverá

Pedro está seguro de ganar/que ganará, vs.

Es seguro que Pedro ganará, Seguramente Pedro ganará

18. This process has nothing to do with the passivization of indirect objects, which may result in apparently similar structures:

They persuaded me to marry her $\rightarrow$ I was persuaded to marry her «Me» is an argument of «persuade," i.e. I was object of their persuasion

19. There is an alternative analysis for these structures: subject-to-object raising (cfr. section A, above) operates first («Everybody knows that he is a spy» $\rightarrow$ «Everybody knows him to be a spy») and then passivization of the raised object («He is known to be a spy»). 


\section{Works Cited}

Akmajian, Adrian. «The Complement Structure of Perception Verbs in an Autonomous Syntax Framework.» Formal Syntax. Ed. Peter Culicover, Thomas Wasow and Adrian Akmajian. New York: Academic P, 1977. 427-460.

Cano Aguilar, Rafael. Estructuras sintácticas transitivas en el español actual. Madrid: Gredos, 1981.

Culicover, Peter. Syntax. New York: Academic P, 1982.

Huddleston, Rodney. An Introduction to English Transformational Syntax. London: Longman, 1976.

. An Introduction to the Grammar of English. Cambridge: Cambridge UP, 1984.

Garrudo, Francisco. «Some Aspects of Contrastive Syntax: Clause Reduction and Raising.» Aspects of Linguistics and Language Teaching. Sevilla: Publicaciones del I. C. E. de la Universidad de Sevilla, 1988. 57-71.

Matthews, Peter Hugoe. Syntax. Cambridge: Cambridge UP, 1981.

Palmer, Frank. The English Verb. London: Longman, 1974.

Postal, Paul. On Raising. Cambridge, Massachusetts: M. I. T., 1974.

Radford, Andrew. Transformational Syntax. Cambridge: Cambridge UP, 1981. 